\title{
Correction to: Intravenous patient- controlled analgesia: in vitro stability profiles of mixtures containing fentanyl, hydromorphone, oxycodone, nefopam, ondansetron, and ramosetron
}

\author{
Chung Hun Lee, Ah Rahn Kim, Mi Kyoung Lee, Jung Suk Oh, Dong Kyu Lee and Sang Sik Choi*
}

Correction to: J Anal Sci Technol 11, 32 (2020) https://doi.org/10.1186/s40543-020-00230-w

Following publication of the original article (Lee et al. 2020), the authors identified an error in the author name of Ah Rahn Kim.

1. Incorrect name:

Ah. Rahn Kim

2. Correct name:

Ah Rahn Kim

The author group has been updated above and the original article (Lee et al. 2020) has been corrected.

Published online: 09 September 2020

\section{Reference}

Lee $\mathrm{CH}$, et al. Intravenous patient-controlled analgesia: in vitro stability profiles of mixtures containing fentanyl, hydromorphone, oxycodone, nefopam, ondansetron, and ramosetron. J Anal Sci Technol. 2020;11:32. https:/doi.org/ 10.1186/s40543-020-00230-w.

\footnotetext{
The original article can be found online at https://doi.org/10.1186/s40543020-00230-w.

*Correspondence: clonidine@empal.com

Department of Anesthesiology and Pain Medicine, Korea University Medical Center, Guro Hospital, Gurodong Road 148, Guro-Gu, Seoul 08308, Republic of Korea
}

(c) The Author(s). 2020 Open Access This article is licensed under a Creative Commons Attribution 4.0 International License which permits use, sharing, adaptation, distribution and reproduction in any medium or format, as long as you give appropriate credit to the original author(s) and the source, provide a link to the Creative Commons licence, and indicate if changes were made. The images or other third party material in this article are included in the article's Creative Commons licence, unless indicated otherwise in a credit line to the material. If material is not included in the article's Creative Commons licence and your intended use is not permitted by statutory regulation or exceeds the permitted use, you will need to obtain permission directly from the copyright holder. To view a copy of this licence, visit http://creativecommons.org/licenses/by/4.0/. 